\title{
Occurrence and study of powdery mildew disease of fenugreek (Trigonella foenum-graecum L.) in South Gujarat
}

\author{
A.U. Gojiya* and J.R. Pandya
}

Department of Plant Pathology, N.M. College of Agriculture, Navsari Agricultural University, Navsari (Gujarat) India

\section{ARITCLE INFO}

Received : 19.01 .2019

Revised : 11.03 .2019

Accepted : 18.03 .2019

\section{KEY WORDS :}

Powdery mildew, Erysiphe hyperici (Wallr. S Bulmer), Erysiphe polygoni, Fenugreek, Survey

*Corresponding author:

Email : amit.gojiya144@gmail.com

\begin{abstract}
Survey of powdery mildew of fenugreek in Navsari district revealed that at flowering and pod formation stages, higher average intensity of 20.67 and 51.11 per was recorded in KVK, Navsari area and least was in 9.78 and 31.33 per cent Sandalpore village, respectively. Total average PDI of Navsari district was recorded 12.96 and 36.85 respectively, at flowering stage and pod formation stage of crop. The average length of conidia was maximum $49.76 \mu \mathrm{m}$ in the samples collected from KVK, Navsari area, while minimum $38.08 \mu \mathrm{m}$ was in the samples collected from Pethan village. Maximum breadth of conidia $21.55 \mu \mathrm{m}$ in KVK, Navsari area and minimum $18.00 \mu \mathrm{m}$ in Pethan village of Navsari district. The average length and breadth of conidia of all villages $43.73 \mu \mathrm{m}$ length and breadth $20.24 \mu \mathrm{m}$, respectively. While length/breadth index was maximum $2.30 \mu \mathrm{m}$ in KVK, Navsari area followed by Abrama 2.09 among the collected samples. In case of conidiophore maximum length in KVK, Navsari area $68.43 \mu \mathrm{m}$ and minimum length in Crafeat area $58.83 \mu \mathrm{m}$. While, maximum length of conidiophores was recorded in KVK, Navsari area $6.78 \mu \mathrm{m}$ and minimum in Cafetra $8.48 \mu \mathrm{m}$. The average of length and width of conidiophore was $63.73 \mu \mathrm{m}$ and $7.67 \mu \mathrm{m}$, respectively.
\end{abstract}

How to view point the article : Gojiya, A.U. and Pandya, J.R. (2019). Occurrence and study of powdery mildew disease of fenugreek (Trigonella foenum-graecum L.) in South Gujarat. Internat. J. Plant Protec., 12(1) : 58-61, DOI : 10.15740/HAS/IJPP/12.1/58-61, Copyright@ 2019: Hind Agri-Horticultural Society. 